Article

\title{
Impact of Particle Sizes, Mineralogy and Pore Fluid Chemistry on the Plasticity of Clayey Soils
}

\author{
Jongmuk Won ${ }^{1}$, Junghee Park ${ }^{2}$, Junki Kim ${ }^{1}$ and Junbong Jang ${ }^{3, *}$ \\ 1 Department of Civil and Environmental Engineering, University of Ulsan, Daehak-ro 93, Nam-gu, \\ Ulsan 44610, Korea; jmwon@ulsan.ac.kr (J.W.); kimjk0929@ulsan.ac.kr (J.K.) \\ 2 School of Civil, Environmental and Architectural Engineering, Korea University, 145 Anam-ro, Seongbuk-gu, \\ Seoul 02841, Korea; junghee.park1905@gmail.com \\ 3 Department of ICT Integrated Ocean Smart City Engineering, Dong-A University, 37 Nakdong-daero 550 \\ beon-gil, Busan 49315, Korea \\ * Correspondence: jjang@dau.ac.kr; Tel.: +82-51-200-7622
}

Citation: Won, J.; Park, J.; Kim, J.;

Jang, J. Impact of Particle Sizes,

Mineralogy and Pore Fluid Chemistry on the Plasticity of Clayey Soils. Sustainability 2021, 13, 11741. https:// doi.org/10.3390/su132111741

Academic Editor: Castorina Silva Vieira

Received: 28 September 2021

Accepted: 21 October 2021

Published: 24 October 2021

Publisher's Note: MDPI stays neutral with regard to jurisdictional claims in published maps and institutional affiliations.

Copyright: (c) 2021 by the authors. Licensee MDPI, Basel, Switzerland. This article is an open access article distributed under the terms and conditions of the Creative Commons Attribution (CC BY) license (https:// creativecommons.org/licenses/by/ $4.0 /)$.

\begin{abstract}
The current classification of clayey soils does not entail information of pore fluid chemistry and particle size less than $75 \mu \mathrm{m}$. However, the pore fluid chemistry and particle size (at given mineralogy) are critical in the plasticity of clayey soils because of their impact on negative charge density. Therefore, this study extensively discusses the description of clay with respect to mineralogy, particle sizes, and pore fluid chemistry based on liquid and plastic limits of kaolinite, illite, and bentonite, and estimates undrained shear strength from the observed liquid limits. The liquid limits and undrained shear strength estimated from the observed liquid limits as a function of mineralogy (clay type), particle size, and ionic concentration reveal the need of incorporating pore fluid chemistry and particle size into the fines classification system. Furthermore, multiple linear regression models developed in this study demonstrate the importance of particle size and ionic concentration in predicting the liquid limit of clayey soils. This study also discusses the need for a comprehensive understanding of fines classification for proper interpretation of natural phenomena and engineering applications for fine-grained sediments.
\end{abstract}

Keywords: clay; mineralogy; particle size; soil classification; liquid limit; pore fluid chemistry

\section{Introduction}

Clay minerals in soils are classified as phyllosilicates that contain layer silicates, and negative electrical charges (in neutral $\mathrm{pH}$ ) on the clay mineral particle surfaces are commonly observed [1]. The unbalanced surface charges prompt inter-particle forces that fine clay mineral particles can form different particle associations such as aggregation or flocculation when subjected to various $\mathrm{pH}$ and ionic concentrations. In particular, the charged particle surfaces cause face-to-face, edge-to-edge, edge-to-face, and shifted faceto-face associations [1-4]. The variation of clay fabrics related to their sensitivity to pore fluid chemistry becomes more pronounced under extreme $\mathrm{pH}$ and ionic concentration conditions $[5,6]$. The electrical-force-dependent fines are more prominent when the particle sizes are smaller [7]. The clay based on textural soil classification is the particles less than $2 \mu \mathrm{m}$ [8]. Generally, clay-sized clay mineral particles show pore fluid dependent behavior and can be classified as clayey soils based on soil classification for engineering purposes, such as the unified soil classification system (USCS).

Clearly, the pore fluid chemistry appears to be critical in the determination of engineering properties and behavior of clayey soils [9,10]; yet, no descriptions of pore fluid chemistry are involved in the current soil classification systems, i.e., USCS, because the alternation of pore fluid chemistry caused by fluid flow in clayey soils prevails in the natural subsurface, and thus clayey soil classification using a certain fluid (i.e., deionized water) may not be appropriate. For example, clayey soils in the mineralogical aspect could 
be classified as silty soils (i.e., silt or elastic silt in USCS) at a specific pore fluid chemistry, which misinterprets the soil layer for engineering designs. The Atterberg limits in USCS can quantify plasticity that distinguish silts and clays. However, mineralogy of particles, particle sizes, and pore fluid chemistry affect the liquid limit and alter soil behaviors.

This study investigates the impact of particle sizes, pore fluid chemistry (ionic concentration), and mineralogy on the plasticity of fines within the Atterberg limits framework. The Atterberg limits measured for illite, kaolinite, and bentonite with different particle sizes and ionic concentrations are plotted in Casagrande's plasticity chart. Discussion emphasizes the distinct different responses of fines and the chance of being classified in different categories due to the alternation of particle sizes and ionic concentrations. Furthermore, the estimation of undrained shear strength from the observed liquid limit is presented to discuss the impact of ionic concentration on undrained shear strength. Finally, the multiple linear regression model is introduced to incorporate mean grain size and ionic concentration as primary predictors for liquid limit predictions.

\section{Methods}

\subsection{Materials}

We selected three natural soils that are commercially available, and each of them mainly consist of kaolinite, illite, and montmorillonite, respectively. Hence, three fines are referred to as kaolinite, illite, and bentonite throughout this study. Kaolinite consists of one tetrahedral sheet and one octahedral sheet (1:1 clay mineral), illite is a 2:1 clay mineral (one octahedral sheet located between two tetrahedral sheets) with potassium between the sheet, and the montmorillonite is a 2:1 clay mineral that adsorbs water between the sheets and swells $[1,11]$. These three clay minerals are common in geotechnical applications, showing different physical behavior because of the distinct mineral structure abovementioned.

For mineralogical information of three natural soils, X-ray diffractions (XRD, Empyrean, PANalytical Inc., Westborough, MA) were performed: the $2 \theta$ scan range is $3^{\circ}-65^{\circ}$ with $0.01^{\circ}$ step size, 0.25 time per step at generator tension $40 \mathrm{kV}$ and generator current $30 \mathrm{~mA}$. X-ray fluorescence (XRF, PW 2404, Malvern Panalytical Inc., Westborough, MA and SPECTRO xSORT, SPECTRO Analytical Instruments $\mathrm{GmbH}$, Boschstr, Germany), and scanning electron microscope with energy dispersive spectroscopy (SEM-EDS, JSM-6700F, JEOL, Tokyo, Japan) provided chemical compositions of the soils. XRD, XRF and SEM-EDS were performed on dry powder conditions of the soils.

\subsection{Geotechnical Properties and Liquid Limit}

For the basic characterization of physical properties for tested clay samples, we measured the specific gravity (Gs; pycnometer, ASTM D854 [12]), particle size distribution (PSD; hydrometer test, ASTM D422 [13]), plastic limit (PL; the rolling thread method, ASTM D4318 [14]), and liquid limit (LL; fall cone test, BS 1377 [15]). We used the sieve of \#200, \#325, and \#500 (corresponding to the opening size of 74,45 , and $30 \mu \mathrm{m}$ ) to only prepare finer soils from original soils. The liquid limits correspond to the water content at a $20 \mathrm{~mm}$ penetration depth of a 30 degree apex steel cone into the fine paste. Note that the $20 \mathrm{~mm}$ penetration corresponds to the undrained shear strength of $1.7-2.7 \mathrm{kPa}$ and suction of approximately $6 \mathrm{kPa}[1,16]$. As the brines can be dried and become higher concentration during the measurements, the fall cone tests were conducted from the dry side to wet side while the liquid evaporated during the measurements was added into the sample to maintain the constant concentration.

In order to investigate the effect of particles on the liquid limit, we obtain smaller particles from original three soils: illite with the sieves of \#200, \#325, and \#500; kaolinite and bentonite with the sieve \#325. Additionally, we conducted the liquid limit tests with varied ionic concentrations to represent pore fluid of freshwater, normal seawater (approximately $0.6 \mathrm{M}$ ), and high concentrated brine in the ocean. The pore fluids used in this experimental study were deionized water (DW, electrical resistivity $>18 \mathrm{M} \Omega$ ) and brines with ionic concentrations of $0.01 \mathrm{M}, 0.05 \mathrm{M}, 0.1 \mathrm{M}, 1 \mathrm{M}$, and $2 \mathrm{M}$ (controlled by $\mathrm{NaCl}$ ). Note that the 
ionic concentration of $2 \mathrm{M} \mathrm{NaCl}$ solution can represent the extreme case of brine to collapse the diffused double layer [16]. The tested materials and experimental conditions in this study enable showing the soil behavior as a function of the particle sizes, mineralogy, and pore fluid chemistry (ionic concentration). Table 1 shows the experimental cases of liquid limit tests. The liquid limit test provides a reliable response of fines without segregation at given pore fluid chemistry with consideration of soil fabric changes due to the pore fluid chemistry [16].

Table 1. Ionic concentration cases of fall cone tests with different soil conditions.

\begin{tabular}{|c|c|c|c|c|}
\hline \multirow[b]{2}{*}{ Name } & \multicolumn{4}{|c|}{ Particle Sizes } \\
\hline & $\begin{array}{c}\mathrm{D}<100 \mu \mathrm{m} \\
\text { (No Sieving) }\end{array}$ & $\begin{array}{c}\mathrm{D}<75 \mu \mathrm{m} \\
(\# 200 \text { Sieve) }\end{array}$ & $\begin{array}{c}\mathrm{D}<44 \mu \mathrm{m} \\
(\# 325 \text { Sieve) }\end{array}$ & $\begin{array}{c}\mathrm{D}<30 \mu \mathrm{m} \\
(\# 500 \text { Sieve })\end{array}$ \\
\hline Illite & $\mathrm{DW} \sim 2 \mathrm{M}$ & $\mathrm{DW} \sim 2 \mathrm{M}$ & $\mathrm{DW} \sim 2 \mathrm{M}$ & $\mathrm{DW} \sim 2 \mathrm{M}$ \\
\hline Kaolinite & $\mathrm{DW} \sim 2 \mathrm{M}$ & - & $\mathrm{DW} \sim 2 \mathrm{M}$ & - \\
\hline Bentonite & $\mathrm{DW} \sim 2 \mathrm{M}$ & - & $\mathrm{DW} \sim 2 \mathrm{M}$ & - \\
\hline
\end{tabular}

\subsection{Theoretical and Empirical Methods for Estimation of Undrained Shear Strength}

The undrained shear strength of fine-grained soils can be estimated by the theory of the fall cone test $[17,18]$. The fall cone factor $(\mathrm{K})$ with the consideration of dynamic penetration of cone can be expressed as:

$$
\mathrm{K}=\frac{3 \zeta}{\pi \mathrm{N}_{\mathrm{ch}} \tan ^{2}(\beta / 2)}
$$

where $\zeta$ is the ratio between $s_{u}$ and dynamic undrained shear strength $\left(s_{u d}\right)\left(=s_{u} / s_{u d}\right)$, $\mathrm{N}_{\mathrm{ch}}$ is a bearing capacity factor with the consideration of heave, and $\beta$ is cone apex angle $\left(30^{\circ}\right.$ in this study). By taking $\zeta=0.744, \mathrm{~N}_{\mathrm{ch}}=7.457$, and $\beta=30^{\circ}$ for $30^{\circ}$ cone used in this study, $\mathrm{K}$ is evaluated as 1.33. Note that the cone surface of medium roughness (roughness factor $=0.5,[18]$ ) was assumed in this calculation because $\mathrm{N}_{\mathrm{ch}}$ is a function of surface roughness of cone. Now, the relationship between water content $(\mathrm{w})$ and the cone penetration (h) can be written as:

$$
\mathrm{w}(\%)=\mathrm{a}\left(\frac{\mathrm{KQ}}{\mathrm{p}_{\mathrm{a}} \mathrm{h}^{2}}\right)^{-\mathrm{b}}=\mathrm{Ah}^{\mathrm{B}}
$$

where $\mathrm{Q}$ is the load applied to the fines ( $=0.8 \mathrm{~N}$ for fall cone apparatus used in this study), $\mathrm{p}_{\mathrm{a}}$ is atmospheric pressure $(\sim 100 \mathrm{kPa})$, and $\mathrm{a}, \mathrm{b}, \mathrm{A}$, and $\mathrm{B}$ are the fitting parameters. By taking the undrained shear strength $\mathrm{s}_{\mathrm{u}}=\mathrm{KQ} / \mathrm{h}^{2}$, Equation (2) can be rewritten as:

$$
\mathrm{s}_{\mathrm{u}}=\mathrm{p}_{\mathrm{a}}\left(\frac{\mathrm{w}(\%)}{\mathrm{a}}\right)^{-1 / \mathrm{b}}
$$

From the result of each fall cone test, $a$ and $b$ can be evaluated in the least square sense using Equation (2), followed by the estimation of $s_{\mathfrak{u}}$ as a function of water content using Equation (3).

\section{Results}

\subsection{Particle Sizes and Shapes}

Figure 1 and Table 2 show particle size distributions of samples used in this study. The results of the hydrometer test presented in Figure 1 show that the median particle sizes of illite and kaolinite are more or less similar while that of bentonite is lower than them although the content of the fines $(<75 \mu \mathrm{m})$ is lower than them (approximately $80 \%$ for bentonite and $90 \%$ for kaolinite and illite). 


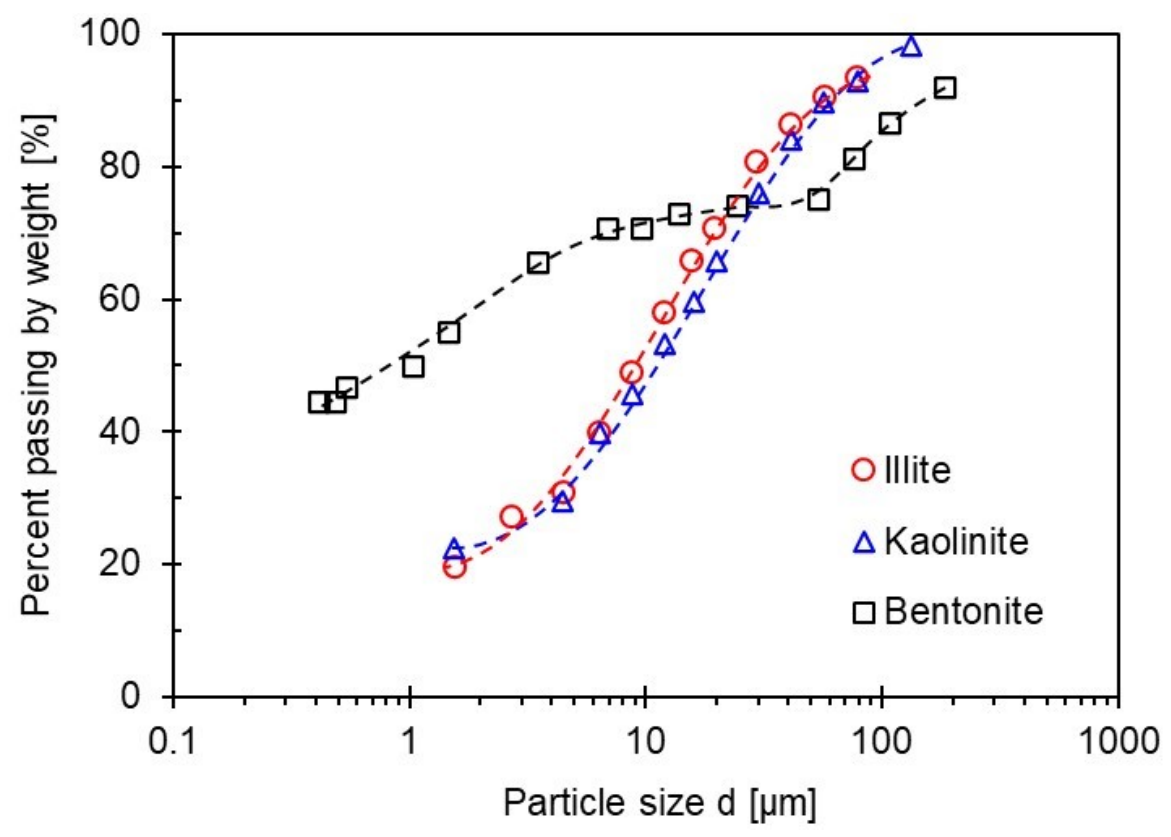

Figure 1. Particle size distribution of three fines used in this study (ASTM D422).

Table 2. Properties of fines used in this study.

\begin{tabular}{cccc}
\hline & Illite & Kaolinite & Bentonite \\
\hline Specific gravity $G_{S}$ & 2.71 & 2.47 & 2.67 \\
Mean grain size $d_{50}(\mu \mathrm{m})$ & 9.0 & 10.5 & 1.0 \\
Coefficient of uniformity $C_{u}$ & 6.43 & 11.87 & - \\
PL $_{\mathrm{DW}}$ & 27 & 31 & 79 \\
LL $_{\mathrm{DW}}$ & 34 & 43 & 300 \\
USCS symbol & $\mathrm{ML}$ & $\mathrm{ML}$ & $\mathrm{CH}$ \\
USCS symbol with 2 M-brine & $\mathrm{ML}$ & $\mathrm{ML}$ & $\mathrm{MH}$ \\
USCS symbol passing sieve \#325 & $\mathrm{ML}$ & $\mathrm{ML}$ & $\mathrm{CH}$ \\
\hline
\end{tabular}

Note: $\mathrm{PL}_{\mathrm{DW}}=$ plastic limit with deionized water, $\mathrm{LL}_{\mathrm{DW}}=$ liquid limit with deionized water, $\mathrm{ML}=$ silt, $\mathrm{MH}=$ elastic silt, $\mathrm{CH}$ = fat clay.

Figure 2 provides the morphology of each fine soil by the scanning electron microscope. Note that the hydrometer test to estimate particle size distribution is based on settling velocity with the assumption of clay particles having a spherical shape. The bentonite particle did not settle down after one week in hexametaphosphate solution (dispersant), therefore the data for the particle size distribution curve less than percent finer than $45 \%$ is not available, leading to no values of coefficient of uniformity $C_{u}$ for bentonite in Table 2 .
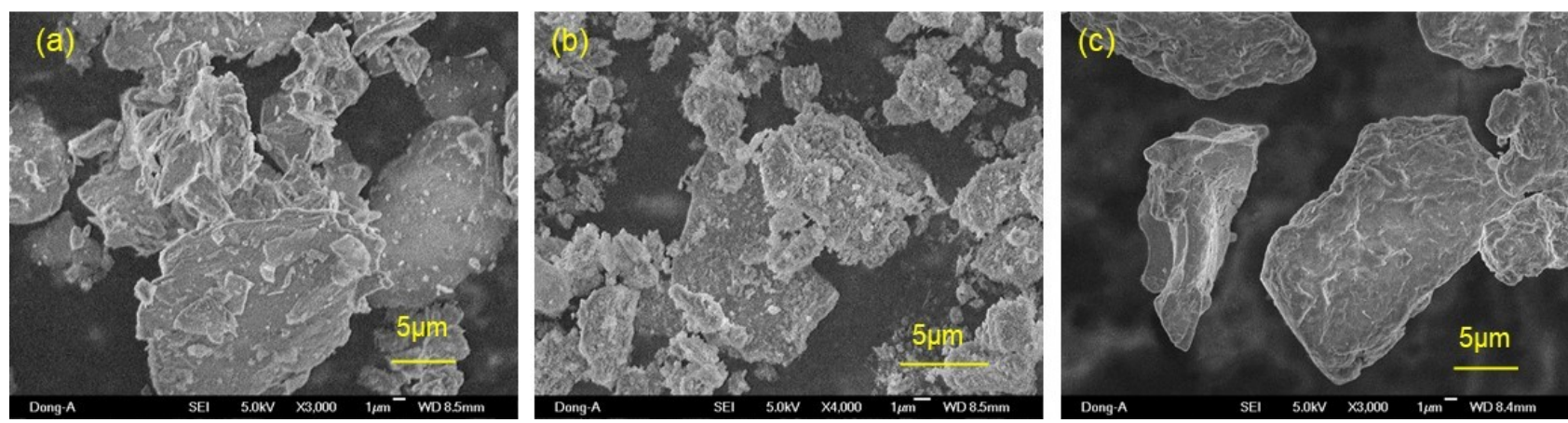

Figure 2. Scanning electron microscope SEM images of three fines: (a) Illite, (b) Kaolinite, and (c) Bentonite. 


\subsection{Mineralogy and Chemical Compositions}

Figure 3 shows XRD patterns of three fines. The peak pattern of the illite shows $52.2 \%$ of illite and muscovite, $42.8 \%$ of quartz, $3.8 \%$ of albite and $1.2 \%$ of hematite. This implied significant quartz content of the illite selected in this study. The bentonite contains $84.6 \%$ of montmorillonite, $11.1 \%$ of albite, $3.0 \%$ of hematite and $1.4 \%$ of quartz. The peak pattern of kaolinite in Figure 3b matches mineral types of kaolinite, halloysite, muscovite, and andesine, but mineralogical quantification was unavailable because of broad peaks. The chemical compositions are identified by XRF (Table 3), which can provide additional information for mineralogy analysis. The XRF data shows major chemical compositions among all oxides.
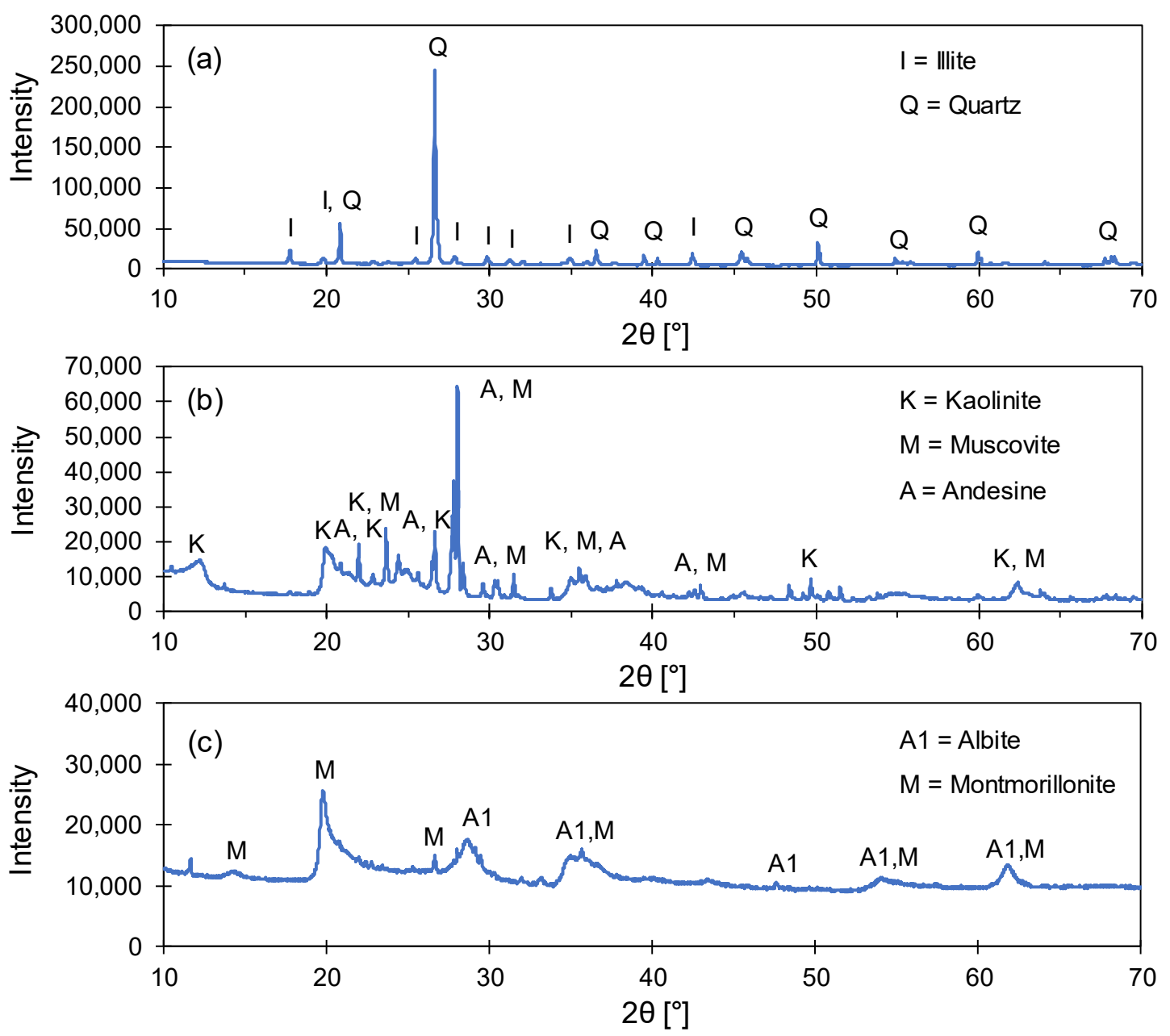

Figure 3. X-ray diffraction patterns of three tested clays: (a) Illite (b) Kaolinite and (c) Bentonite.

Table 3. Major chemical compositions of three fines by XRF.

\begin{tabular}{cccc}
\hline Composition & $\begin{array}{c}\text { Fine 1 } \\
\text { (Illite) }\end{array}$ & $\begin{array}{c}\text { Mass Percentage (\%) } \\
\text { Fine 2 (Kaolinite) }\end{array}$ & $\begin{array}{c}\text { Fine 3 } \\
\text { (Bentonite) }\end{array}$ \\
\hline $\mathrm{SiO}_{2}$ & 68.45 & 54.84 & 50.8 \\
$\mathrm{Al}_{2} \mathrm{O}_{3}$ & 19.25 & 39.18 & 15.7 \\
$\mathrm{CaO}$ & - & 3.83 & 3.14 \\
$\mathrm{Fe}_{2} \mathrm{O}_{3}$ & 5.21 & 1.45 & 22.1 \\
$\mathrm{~K}_{2} \mathrm{O}$ & 6.22 & 0.42 & 0.247 \\
$\mathrm{TiO}_{2}$ & 0.65 & 0.2 & 1.45 \\
$\mathrm{MnO}$ & 0.09 & - & 0.084 \\
\hline
\end{tabular}




\subsection{Liquid Limits Measured with Fall Cone Tests}

Figure 4 illustrates the fall cone test results of illite, kaolinite, and bentonite as a function of ionic concentration and particle size. For three clay samples, liquid limits decrease when the ionic concentration increases most likely because the pore fluid chemistry alters particle arrangements. At a relatively high ionic concentration such as $2 \mathrm{M}$ brine, platy clay particles form aggregated fabrics with low double layer thickness. This leads to smooth cone penetration at high ionic concentration and resulted in a low liquid limit. In addition, the liquid limits of illite and kaolinite in deionized water presented in Figure 4a,b are comparable to the liquid limit of illite and kaolinite with similar quartz content $(\sim 50 \%)$ presented in the literature [19]. This implies the importance of mineralogical composition on the plasticity of clay minerals.
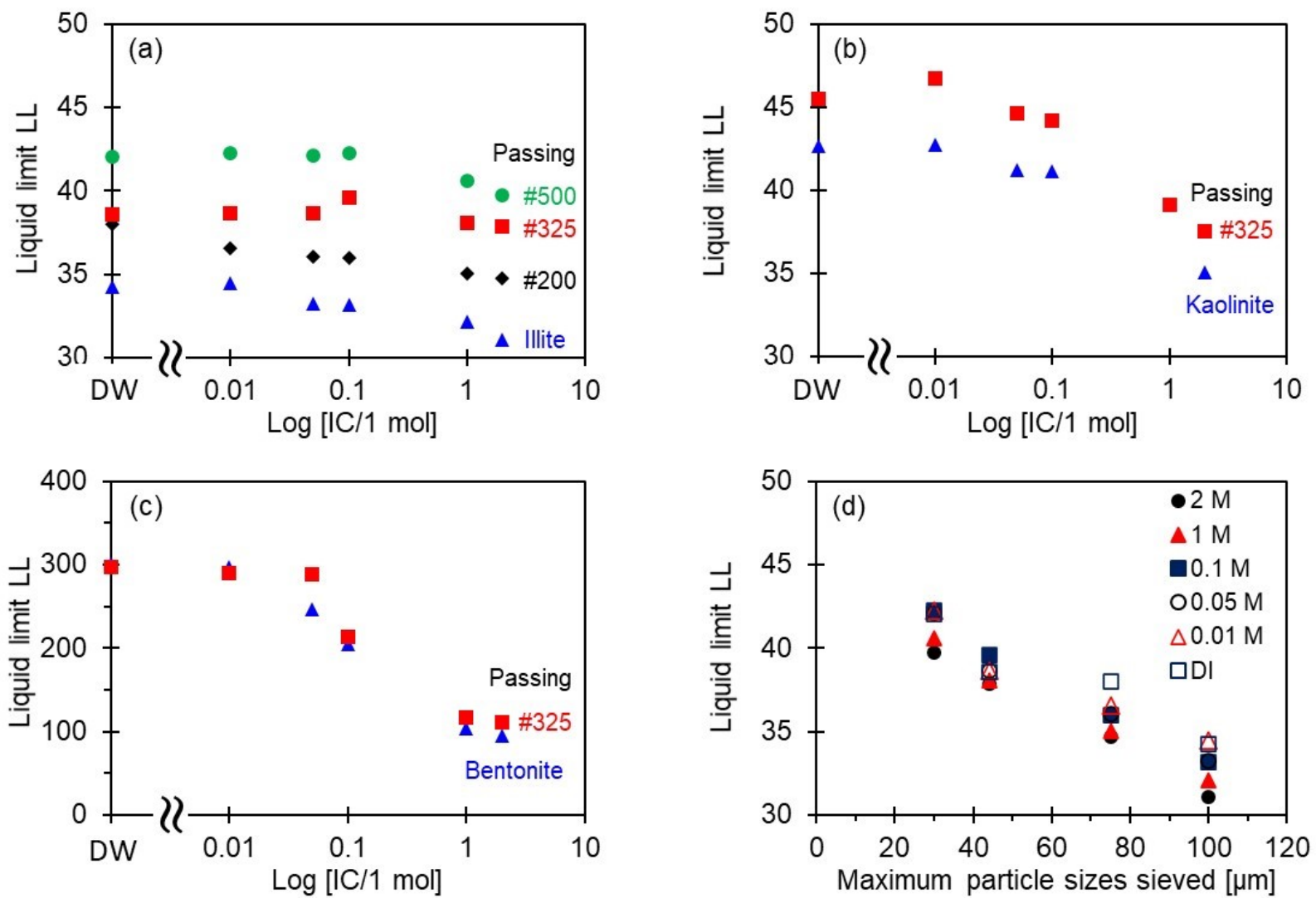

Figure 4. Liquid limit LL versus ionic concentration of pore fluid in logarithmic scale for (a) Illite, (b) Kaolinite, (c) Bentonite, and (d) Liquid limits of illite at different ionic concentrations after sieving.

As seen in Figure 4, bentonite shows the most significant reductions in liquid limit by decreased ionic concentration among three clay minerals. This can be attributed to the most substantial reduction of double-layer thickness by increased $\mathrm{Na}^{+}$ions because bentonite contains high-swelling montmorillonite. Figure $4 \mathrm{a}-\mathrm{c}$ implies the sensitivity of different mineralogy on change in pore fluid chemistry.

As seen in Figure 4, particle sizes of fines less than $75 \mu \mathrm{m}$ also affect liquid limits: the smaller particles show a higher liquid limit most likely because of a higher specific surface. Especially, the liquid limits of illite presented in Figure 4d show the semi-linear reduction in liquid limits as the particle sizes increase. The smaller particles of samples after sieving can hold more water molecules, which leads to an increased liquid limit as sizes of illite and kaolinite particles are decreased (Figure 4a,b). In contrast, because the medium particle size of bentonite is much lower than illite and kaolinite (Figure 1 and Table 2), the liquid limit of bentonite is relatively not sensitive to particle sizes. The particle sizes of the original bentonite are sufficiently low enough to govern the soil arrangement or 
the soil structure regardless of sieving with \#325 sieve. This leads to analogous liquid limits between before and after sieving with \#325 sieve (Figure 4c). The liquid limits presented in Figure 4 implies that the reduction of particle sizes affects more significantly on liquid limits of low-plasticity clay than high-plasticity clay.

\subsection{Statistical Use of Liquid Limit Data}

The availability of liquid limit datasets in literature for a wide range of fine-grained soils, which enables the comparison of test results in this study with previous studies. In this section, we developed correlations between liquid limit values and other mechanical properties of fines.

Correlation matrix between liquid limit and influencing factors. Figure 5 presents the correlation matrix scatter plot of liquid limit data in this study combined with the data presented in [16]. A total of 116 liquid limit data are plotted in Figure 5 for potential influencing factors of mean particle size $\left(D_{50}\right)$, specific surface $\left(S_{a}\right)$, plastic limit $(P L)$, ionic concentration (IC), and relative permittivity $(\mathrm{K})$. The five subset figures in the last row (Figure 5) show the correlation between the logarithm of measured liquid limit $(\log (\mathrm{LL}))$ with a single factor and the rest of the correlations represents the relationship between influencing factors (predictors). Low $p$-values $(<0.05)$ were observed for the relationship between $\log (\mathrm{LL})$ and all factors which indicate $\mathrm{D}_{50}, \mathrm{~S}_{\mathrm{a}}, \mathrm{PL}, \mathrm{IC}$, and $\mathrm{k}$ are likely to be meaningful factors in multiple regression models for predicting liquid limit. In addition, low values of coefficient of determination $\left(\mathrm{R}^{2}\right)$ and high $p$-values between most of the two predictors indicate irrelevancy between predictors. The low $p$-values were observed for relationships between $D_{50}$ and $P L$, and $D_{50}$ and $S_{a}$. This is more or less intuitive because PL is positively correlated with LL for most fine-grained soils and a decrease in $D_{50}$ of soils leads to an increase in $S_{a}$ as presented in Santamarina et al. (2002) [20]. In spite of having dependency of PL and Sa against $\mathrm{D}_{50}, \mathrm{PL}$, and $\mathrm{S}_{\mathrm{a}}$, all factors were included as predictors in the multiple linear regression model in this study because of relatively low $\mathrm{R}^{2}$ values between those predictors. Given the strong negative correlation between IC and $\kappa\left(\mathrm{R}^{2} \sim 1\right.$, $\rho \sim-1$ ), only IC was selected for the regression model. Note that the observed positive correlation between $\log (\mathrm{LL})$ and $\mathrm{S}_{\mathrm{a}}$ is consistent with the previous studies [21-23], and the negative correlation between $\log (\mathrm{LL})$ and $\mathrm{D}_{50}$ is consistent with the observation in Figures 4 and 5 .

Multiple linear regression model. The multiple linear regression model is developed using the data obtained from this study only (Figure 6a). Furthermore, using the data collected from previous studies [24] combined with data in this study, another multiple regression model is presented in Figure $6 b$. High prediction accuracy $\left(R^{2}=0.926\right)$ of the regression model was obtained for data in this study (Figure 6a) while relatively low prediction accuracy of $\mathrm{R}^{2}=0.814$ was obtained for all data. One reason for the low $\mathrm{R}^{2}$ value in Figure $6 \mathrm{~b}$ is attributed to including data of the relatively large size of soils $(>20 \mu \mathrm{m})$ and non-geomaterials such as diatom. Excluding those data yields a higher $\mathrm{R}^{2}$ value of 0.853. The main advantage of using the multiple regression models presented in this study is the ability to take 4 predictors $\left(S_{a}, D_{50}, I C\right.$, and PL) into consideration including ionic concentration for predicting liquid limit. In case of some predictors are missing, the regression model presented in Table 4 may be used even though the accuracy is lower than the case of all predictors available. Note that the result of taking single predictor PL in the last row of Table 4 is identical to the result of PL against log (LL) in Figure 6. 


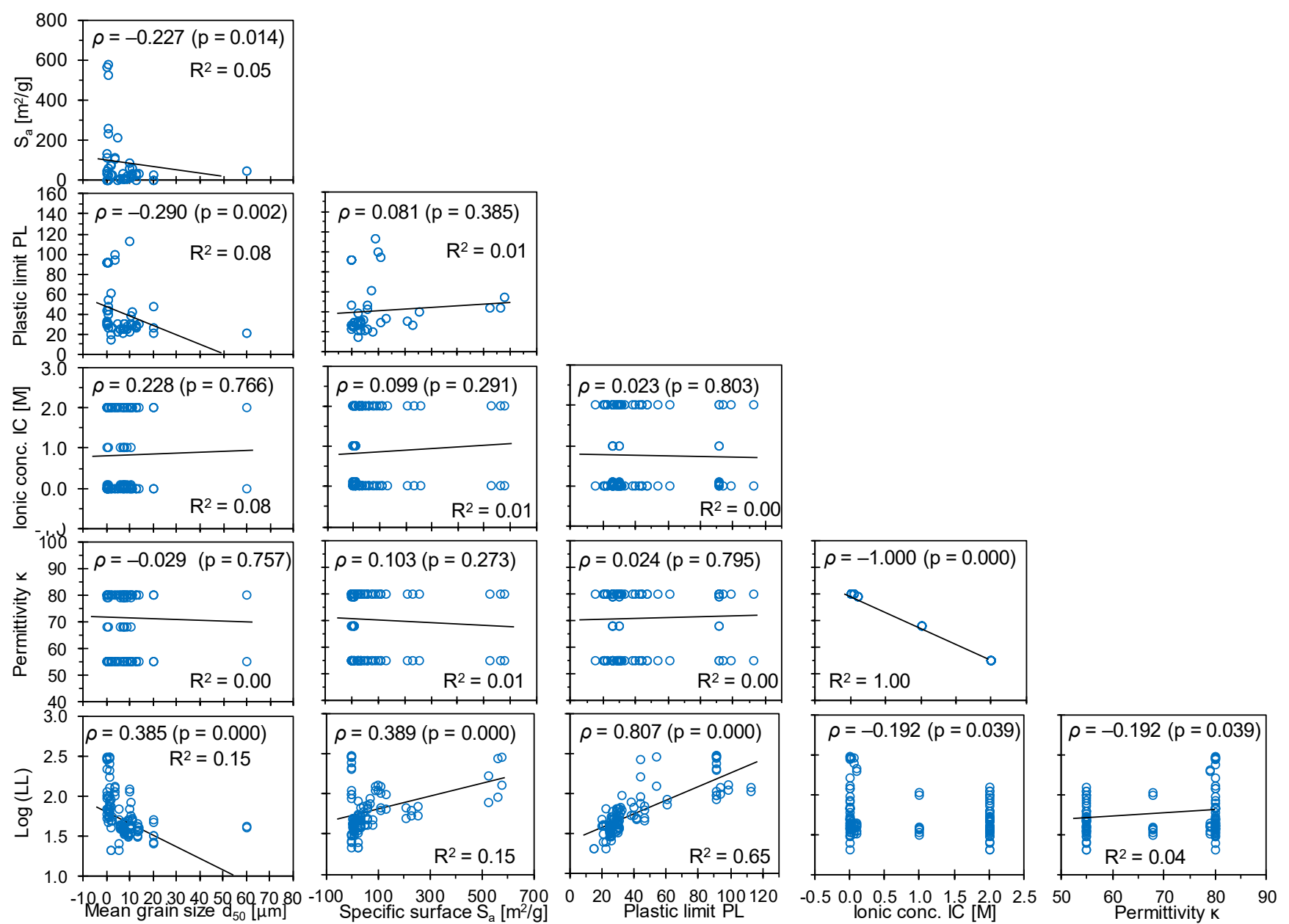

Figure 5. Correlation matrix of the dataset used in the regression analysis. Note that $\rho=$ Pearson coefficient and $p=p$-value.
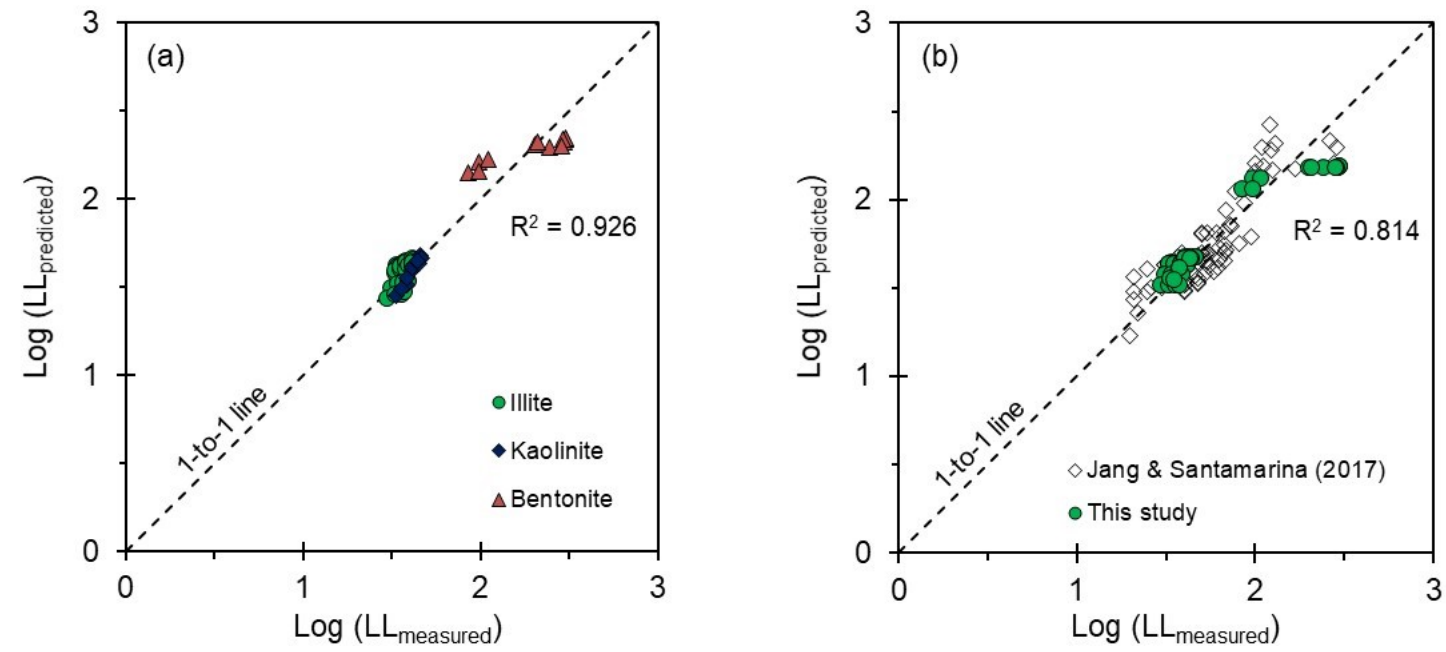

Figure 6. Developed multiple linear regression models: (a) Data obtained in this study where $\log (\mathrm{LL})=0.013 \mathrm{~S}_{\mathrm{a}}+0.009 \mathrm{PL}$ $-0.089 \mathrm{IC}+1.478$ and $(\mathbf{b})$ Data combined with Jang and Santamarina $(2017)$ where $\log (\operatorname{LL})=\left(-3.11 \times 10^{-4}\right) \mathrm{D}_{50}+$ $\left(7.43 \times 10^{-4}\right) \mathrm{S}_{\mathrm{a}}-\left(7.44 \times 10^{-4}\right) \mathrm{PL}-\left(6.33 \times 10^{-2}\right) \mathrm{IC}+1.4188$. 
Table 4. Results of multiple linear regression.

\begin{tabular}{|c|c|c|c|c|c|c|c|}
\hline Data & $\beta_{0} \times 10^{3}$ & $\beta_{1} \times 10^{3}$ & $\beta_{2} \times 10^{3}$ & $\beta_{3} \times 10^{3}$ & $\beta_{4} \times 10^{3}$ & $\mathbf{R}^{2}$ & Selected Predictors \\
\hline \multirow{4}{*}{ This study } & 1478.6 & -13.05 & 0 & 9.36 & -89.15 & 0.926 & $\begin{array}{c}S_{a}, D_{50}, \mathrm{IC} \text {, and PL } \\
\text { (Figure 6a) }\end{array}$ \\
\hline & 1478.6 & $\mathrm{~N} / \mathrm{A}$ & -13.05 & 9.36 & -89.15 & 0.926 & $D_{50}, \mathrm{IC}$, and $\mathrm{PL}$ \\
\hline & 1336.3 & $\mathrm{~N} / \mathrm{A}$ & $\mathrm{N} / \mathrm{A}$ & 10.82 & -89.15 & 0.923 & IC and PL \\
\hline & 1289.4 & $\mathrm{~N} / \mathrm{A}$ & $\mathrm{N} / \mathrm{A}$ & $\mathrm{N} / \mathrm{A}$ & 10.82 & 0.880 & PL \\
\hline \multirow{4}{*}{ All data } & 1440.8 & -2.74 & 0.71 & 8.23 & -59.99 & 0.807 & $\begin{array}{c}S_{a}, D_{50,}, \mathrm{IC} \text {, and PL } \\
\text { (Figure 6b) }\end{array}$ \\
\hline & 1493.4 & $\mathrm{~N} / \mathrm{A}$ & -5.06 & 8.30 & -49.82 & 0.705 & $D_{50}, \mathrm{IC}$, and PL \\
\hline & 1437.0 & $\mathrm{~N} / \mathrm{A}$ & $\mathrm{N} / \mathrm{A}$ & 8.81 & -50.82 & 0.682 & IC and PL \\
\hline & 1394.3 & $\mathrm{~N} / \mathrm{A}$ & $\mathrm{N} / \mathrm{A}$ & $\mathrm{N} / \mathrm{A}$ & 88.57 & 0.652 & $\begin{array}{l}\text { PL (PL versus log } \\
\text { (LL) in Figure 5) }\end{array}$ \\
\hline
\end{tabular}

Note: $\log (\mathrm{LL})=\beta_{0}+\beta_{1} S_{a}\left(\mathrm{~m}^{2} / \mathrm{g}\right)+\beta_{2} \mathrm{D}_{50}(\mu \mathrm{m})+\beta_{3} \mathrm{IC}+\beta_{4} \mathrm{PL}(\%)$.

\subsection{Estimated Undrained Shear Strength}

The $\mathrm{h}-\mathrm{w}$ relationship is a function of clay and ionic concentration; therefore the a and b constants can be evaluated for each test condition as presented in Table 5. By obtaining a and $b$ constants, $s_{u}$ of fines can be estimated at given $w$. Figure 7 illustrates the estimated $\mathrm{s}_{\mathrm{u}}$ of three clays for the water content ranged from the plastic limit at deionized water and the liquid limit presented in Figure 4. Overall, $s_{\mathrm{u}}$ nonlinearly decreases as water content increases, which can be explained by low shear resistance at cone-clay interface under high water content. In addition, $s_{\mathrm{u}}$ decreases as ionic concentration increases for three clays (discussed later in the discussion section), and the bentonite show the lowest $\mathrm{s}_{\mathrm{u}}$ among three clays. The results presented in Figure 7 imply the notable variation of $s_{u}$ caused by the alternation of ionic concentration and water content. Note that no trend was found for the $\mathrm{a}$ and $\mathrm{b}$ values in Table 5 as a function of ionic concentration because of their best-fitted nature and high $R^{2}$ values $\left(R^{2}>0.9\right)$ were obtained except for a few cases.

Table 5. Evaluated Fitting Parameters $a$ and $b$ in Equation (3) for observed data in liquid limit test and coefficient of determination $\left(\mathrm{R}^{2}\right)$.

\begin{tabular}{|c|c|c|c|c|c|c|c|c|c|}
\hline Name & IC (M) & $a$ & $b$ & $\mathbf{R}^{2}$ & Name & IC (M) & $a$ & $b$ & $\mathbf{R}^{2}$ \\
\hline \multirow{6}{*}{ Illite } & 0 & 24.26 & 0.10 & 0.99 & \multirow{6}{*}{ Kaolinite } & 0 & 22.71 & 0.17 & 0.99 \\
\hline & 0.01 & 18.90 & 0.17 & 0.99 & & 0.01 & 25.81 & 0.14 & 1.00 \\
\hline & 0.05 & 19.29 & 0.15 & 0.93 & & 0.05 & 23.47 & 0.16 & 1.00 \\
\hline & 0.1 & 20.59 & 0.13 & 0.99 & & 0.1 & 21.06 & 0.18 & 0.99 \\
\hline & 1 & 20.68 & 0.12 & 1.00 & & 1 & 22.87 & 0.14 & 1.00 \\
\hline & 2 & 18.45 & 0.13 & 0.87 & & 2 & 24.93 & 0.08 & 1.00 \\
\hline \multirow{6}{*}{$\begin{array}{c}\text { Illite } \\
(<\# 200)\end{array}$} & 0 & 25.98 & 0.10 & 0.92 & \multirow{7}{*}{$\begin{array}{c}\text { Kaolinite } \\
(<\# 325)\end{array}$} & 0 & 27.08 & 0.14 & 0.98 \\
\hline & 0.01 & 20.82 & 0.16 & 1.00 & & 0.01 & 24.97 & 0.17 & 1.00 \\
\hline & 0.05 & 21.13 & 0.15 & 0.93 & & 0.05 & 27.40 & 0.13 & 1.00 \\
\hline & 0.1 & 20.69 & 0.15 & 0.94 & & 0.1 & 28.41 & 0.12 & 0.95 \\
\hline & 1 & 20.50 & 0.14 & 0.98 & & 1 & 29.06 & 0.08 & 0.99 \\
\hline & 2 & 19.54 & 0.15 & 1.00 & & 2 & 27.08 & 0.08 & 0.99 \\
\hline \multirow{6}{*}{$\begin{array}{c}\text { Illite } \\
(<\# 325)\end{array}$} & 0 & 21.54 & 0.16 & 0.98 & & 0 & 37.70 & 0.57 & 1.00 \\
\hline & 0.01 & 20.99 & 0.17 & 0.95 & \multirow{5}{*}{ Bentonite } & 0.01 & 35.16 & 0.59 & 0.99 \\
\hline & 0.05 & 15.50 & 0.41 & 0.61 & & 0.05 & 45.80 & 0.46 & 0.99 \\
\hline & 0.1 & 23.45 & 0.14 & 0.99 & & 0.1 & 48.30 & 0.39 & 1.00 \\
\hline & 1 & 20.42 & 0.17 & 0.97 & & 1 & 59.20 & 0.14 & 0.97 \\
\hline & 2 & 23.11 & 0.12 & 0.99 & & 2 & 47.34 & 0.16 & 0.89 \\
\hline \multirow{6}{*}{$\begin{array}{c}\text { Illite } \\
(<\# 500)\end{array}$} & 0 & 22.67 & 0.17 & 1.00 & \multirow{6}{*}{$\begin{array}{c}\text { Bentonite } \\
(<\# 325)\end{array}$} & 0 & 52.46 & 0.48 & 1.00 \\
\hline & 0.01 & 21.52 & 0.19 & 0.98 & & 0.01 & 49.96 & 0.48 & 1.00 \\
\hline & 0.05 & 24.63 & 0.15 & 1.00 & & 0.05 & 41.17 & 0.53 & 0.97 \\
\hline & 0.1 & 19.11 & 0.22 & 0.98 & & 0.1 & 44.24 & 0.43 & 0.99 \\
\hline & 1 & 23.49 & 0.14 & 1.00 & & 1 & 70.07 & 0.12 & 0.91 \\
\hline & 2 & 21.54 & 0.16 & 0.99 & & 2 & 65.84 & 0.11 & 0.95 \\
\hline
\end{tabular}



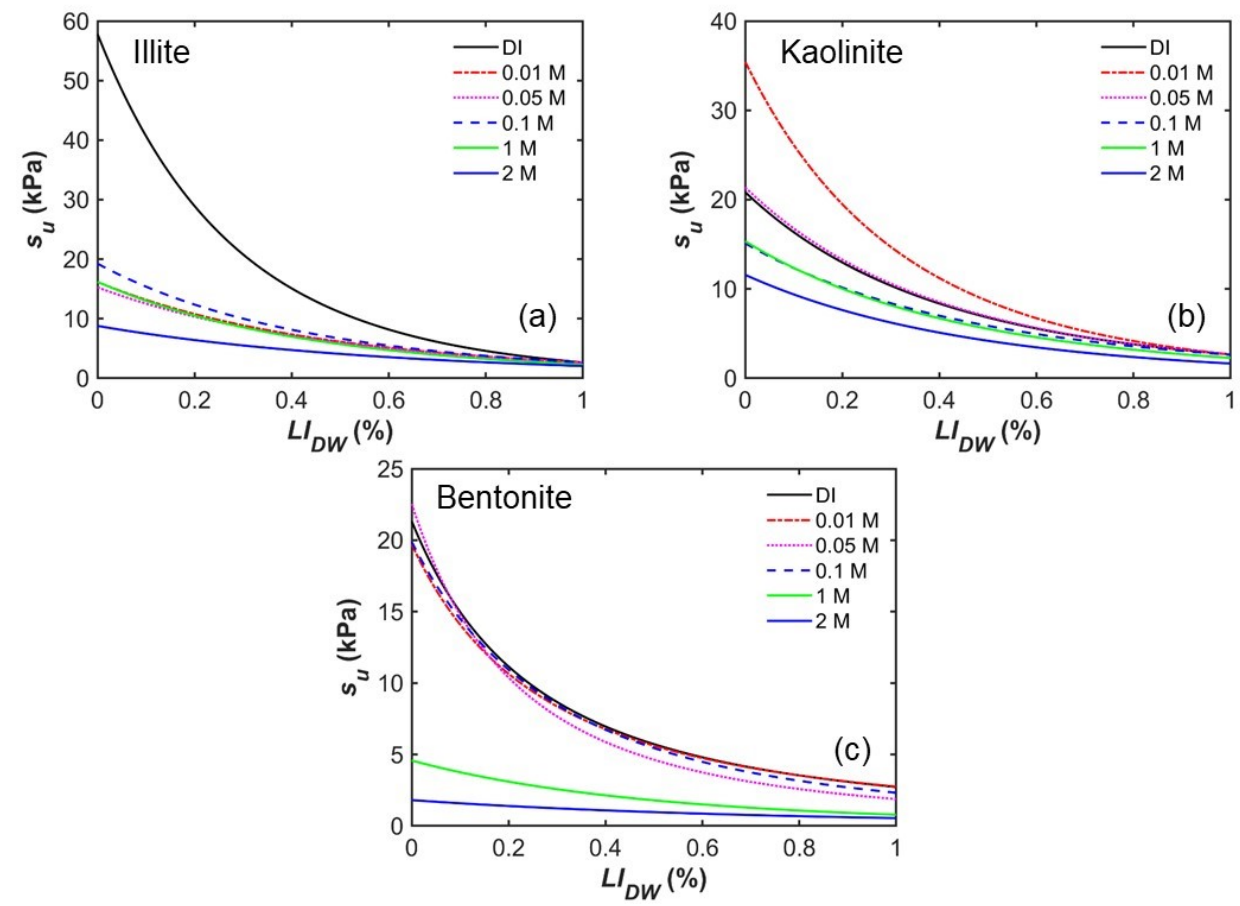

Figure 7. Estimated undrained shear strength $\left(\mathrm{s}_{\mathrm{u}}\right)$ of $(\mathbf{a})$ illite, $(\mathbf{b})$ kaolinite, and (c) bentonite using the evaluated fitting parameter $a$ and $b$ presented in Table $5 . \mathrm{LI}_{\mathrm{DW}}=\left(\mathrm{w}-\mathrm{PL} \mathrm{LW}_{\mathrm{DW}}\right) /\left(\mathrm{LL}-\mathrm{PL} \mathrm{DW}_{\mathrm{D}}\right)$ and water content $(\mathrm{w})$ here is ranged from plastic limit at deionized water ( $P L_{D W}$ in Table 1 ) to liquid limit (Figure 4).

\section{Discussion}

\subsection{Impact of Ionic Concentration on Undrained Shear Strength}

The higher liquid limit at low ionic concentration presented in Figure 4 corresponds to the shallower penetration depth of cone at a low ionic concentration under a certain water content compared to high ionic concentrations. Theoretically, the shallow cone penetration depth indicates that a shear resistance and cone-bearing capacity of soils is high $[17,18,25,26]$. Therefore, the high $\mathrm{s}_{\mathrm{u}}$ at low ionic concentration presented in Figure 7 can be anticipated from the high liquid limit values at low ionic concentration (Figure 4). Equations (1)-(3) can be effectively used to estimate the undrained shear strength of fines from the observed water content versus cone penetration data.

However, it showed the increased undrained shear strength of silt size saturated loess samples with an increase in $\mathrm{NaCl}$ concentration [27]. They revealed that the observed trend of undrained shear strength can be attributed to the increased interparticle forces and the aggregated loess particles caused by increased $\mathrm{NaCl}$ concentration. In contrast, the decreased undrained shear strength of kaolinite was observed with an increased $\mathrm{NaCl}$ concentration [28], which is consistent with the results presented in Figure 7. They explained the edge-to-face association of kaolinite particles in deionized water leads to the high undrained shear strength while the decreased edge-to-face association at relatively high $\mathrm{NaCl}$ concentration causes reduced undrained shear strength. The discrepancy of the tendency of undrained shear strength mentioned above indicates the mineralogy- and size-dependent undrained shear strength behavior of fines under the variation of ionic concentration. Given that the physicochemical interactions between fine particles and their aggregation/flocculation behaviors are mineralogy- and size-dependent [3,4,29], a relatively simple fall cone test can be a useful alternative to capture the trend of undrained shear strength against ionic concentration. Note that the nonlinear relationship between $s_{u}$ and water content and the trend of increasing $\mathrm{s}_{\mathrm{u}}$ as ionic concentration decreases presented in Figure 7 is consistent with the experimental observations presented in [28]. 


\subsection{Fines Classifications for Engineering Purposes}

In the case of soil sediments, geotechnical soil classifications would evaluate the physical and mechanical properties of sediments including lithological information. Figure 8 shows the alternation of position in the plasticity chart caused by increased ionic concentration to $2 \mathrm{M}$-brine and decreased particle size (passing \#325 sieve). As seen in Figure 8b, an increase in ionic strength and particle size decreases plasticity for kaolinite and illite. Thus, Figure 8 shows the need of including particle sizes and mineralogy in the geotechnical soil classification. Even though all data points in Figure $8 \mathrm{~b}$ are in the ML category, the shift of data implies the chance of low-plasticity clay at the site being classified in other categories caused by the alternation of particle size and ionic concentration.
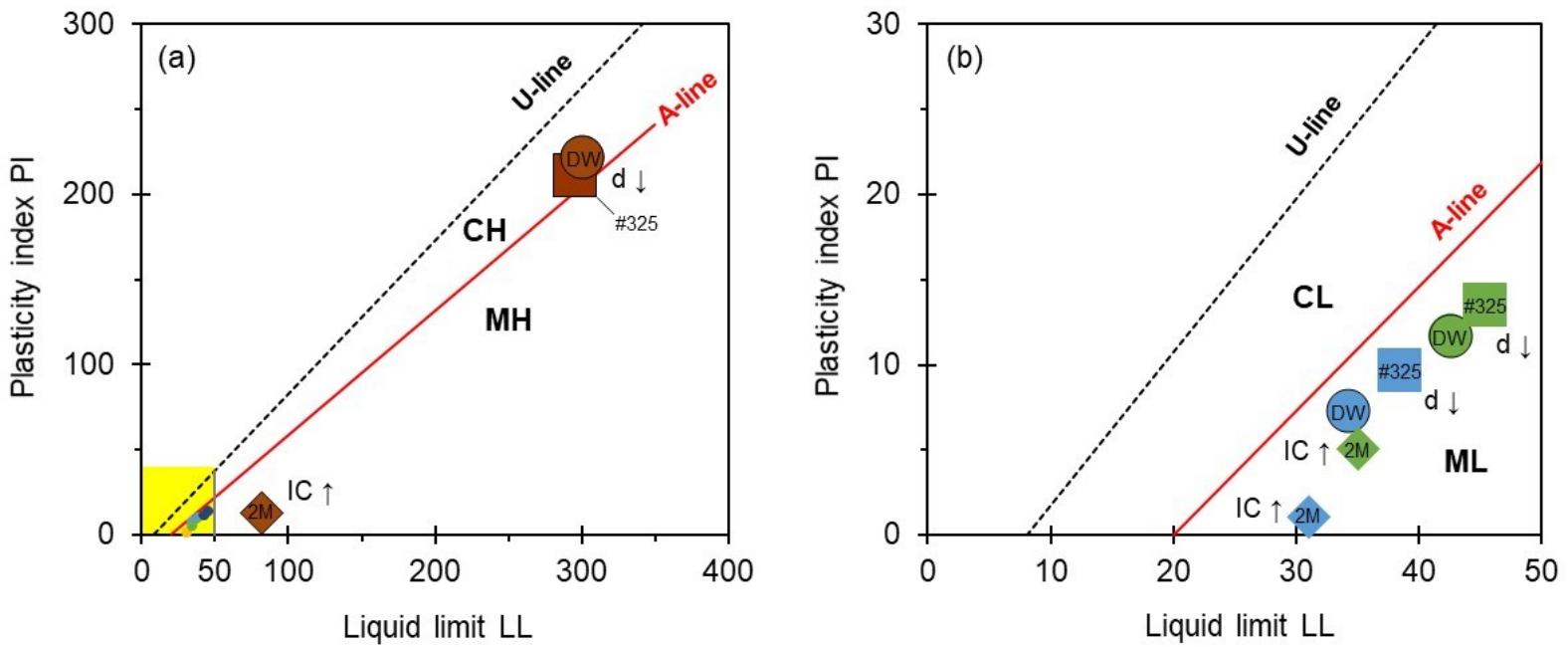

Figure 8. Impacts of particle sizes and ionic concentrations on the plasticity chart for (a) Bentonite and (b) Illite and kaolinite. Legends-blue: illite, green: kaolinite, brown: bentonite. The diamond indicates data with $2 \mathrm{M}$-brine and square indicates data for particles passing sieve \#325.

Figure 8a illustrates the change of fine classification for bentonite caused by the change in ionic concentration. The bentonite with deionized water is classified as $\mathrm{CH}$ but classified as elastic silt $(\mathrm{MH})$ for $2 \mathrm{M}$-brine. This discrepancy indicates the different soil behaviors between marine and fresh-water sediments. Also, this shift can be effectively predicted by electrical sensitivity SE, an index to quantify the sensitivity of fine-grained soils to pore fluid chemistry, allowing the improvement of current soil classification for engineering applications [16]. For example, water-flooding in oil production may use electrical sensitivity to predict soil behavior with pore fluid displacements. The soil classification with pore fluid chemistry could enlighten the physical behaviors of soils with pore fluid displacements in environmental problems and energy fields.

As seen in Table 2 and Figure 8, original kaolinite and illite samples are classified as silt (ML) and the bentonite is classified as fat clay $(\mathrm{CH})$ in the Unified Soil Classification System (USCS), ASTM D2487. The results meet the classification of typical kaolinite and illite in the soil classification where kaolinite and illite fall into ML or $\mathrm{CH}[8,30]$. The soil classification for bentonite is consistent with the classification based on mineralogy, but ML for kaolinite and illite could be inconsistent with clay as the group name of the main minerals that represent silt (M). This is consistent with the size-wise classification of kaolinite and illite because the fraction of particle size $<2 \mu \mathrm{m}$ for kaolinite and illite is less than 30\% (Figure 1). However, mineralogical information (Figure 3 and Table 3 ) of kaolinite and illite reveals the classification of two samples as clay. The typical geotechnical behavior of silt and clay is completely different, and thus classifying fines only by particle size or mineralogy may mislead the prediction of engineering behavior of fines by the soil classification. Therefore, it can be inferred that particle size, mineralogy, and fines classification in geotechnical engineering would be complementary to each other. 


\subsection{Engineering Interpretations to Natural Phenomena}

Field expeditions for offshore and onshore classify soils based on particle sizes and mineralogy to obtain lithological information, which is hinged on physical properties and explains natural phenomena [31,32]. The classification based on particle sizes and mineralogy can be connected to anticipate the physical properties of sediments (e.g., estimation of the permeability by particle sizes $[33,34]$. The physical and mechanical properties of soil formations are critical in quantitative and qualitative analyses of natural phenomena [35], the use of natural resources [36,37].

When a layer of diatom-dominated sediment exists, the porosity would not follow the typical trend of decreasing with depth as the porosity would spike at the depth of diatomdominated sediment because of extraordinary lithological information of mineralogy and particle sizes [31,32]. The combination of amorphous mineral information and siltsized particles with high porosity would confuse the behavior of the sediment. If the Unified Soil Classification System in geotechnical engineering is applied, the diatomdominated sediment would typically fall into elastic silt, $\mathrm{MH}$, which cannot represent the general behavior of internal porosity materials such as diatoms and microfossils. In addition, the ionic concentration could be an important factor for natural hazards such as submarine landslide near brine pool in the Gulf of Mexico [38] and subaerial landslide such as the Rissa landslide [39] because ionic concentration can alter the soil structure and decrease the shear strength. The above-mentioned applications show the insufficiency of incorporating geomaterials in nature and the variation of pore fluid chemistry in the current fines classification system.

Furthermore, reflecting pore fluid chemistry in fines classifications can be utilized to anticipate soil behavior for engineering applications. For example, gas production from methane hydrate dissociation in natural methane-hydrate-bearing sediments offshore produces methane gas and fresh water, which can reduce the salt concentration in pore fluid. The freshen water can affect the compressibility and permeability of clay [31,40]. In order to incorporate the fines behavior due to pore fluid chemistry change, modified fines classification based on liquid limit values could be applied [16]. The change in liquid limit in Figures 4 and 7 show the importance of fines classification with pore-fluid chemistry that can expand the soil classification for complex engineering applications with pore fluid displacement such as enhanced oil recovery and carbon dioxide sequestration.

\section{Conclusions}

"Clay" has been used with multi-semantic definitions by particle sizes, minerals, and plasticity. The classification of clay in soil classification by plasticity represents the physical behavior of clays based on interparticle interactions and soil fabric changes. We conducted the liquid limit test at varied ionic concentrations and particle sizes for kaolinite, illite, and bentonite. A decrease in particle sizes helps the electrical forces through pore fluids between particles overcome gravitational force, and less salinity can lead to higher liquid limits due to the altered electrical interactions between clay particles, mainly caused by the increased diffusive double layer thickness. Accordingly, bentonite showed high liquid limits with high sensitivity to pore fluid chemistry. The correlation matrix plot using collected liquid limit data indicated the pore fluid chemistry as a critical factor for predicting liquid limit. Physically, the liquid limit is hinged on the formation of fabric, which affects key geotechnical parameters such as shear strength. Therefore, soil classification with pore fluid chemistry can provide the response of fine-grained soils against the change of pore fluid. The anticipated behavior of fine-grained soils could be inconsistent with the current fines classification system, and thus fines classification in geotechnical engineering with the utilization of particle size and pore fluid chemistry would improve interpretation of in situ data for natural phenomena. 
Author Contributions: Conceptualization, J.W. and J.J.; methodology, J.W., J.K. and J.J.; formal analysis, J.W., J.P. and J.J.; writing—original draft preparation, J.W.; writing—review and editing, J.P. and J.J.; supervision, J.W. and J.J.; funding acquisition, J.J. All authors have read and agreed to the published version of the manuscript.

Funding: This work was supported by the Dong-A University research fund (Dong-A University: 2020).

Data Availability Statement: The data presented in this study are available on request to the corresponding author.

Acknowledgments: This work was supported by the Dong-A University research fund.

Conflicts of Interest: The authors declare no conflict of interest.

\section{References}

1. Mitchell, J.K.; Soga, K. Fundamentals of Soil Behavior, 3rd ed.; John Wiley and Sons, Inc.: Hoboken, NJ, USA, 2005.

2. Grim, R.E. Applied Clay Mineralogy; McGraw-Hill Book Company, Inc.: New York, NY, USA, 1962.

3. Lambe, T.W.; Whitman, R.V. Soil Mechanics; John Willey \& Sons. Inc.: New York, NY, USA, 1969.

4. Palomino, A.M.; Santamarina, J.C. Fabric map for kaolinite: Effects of $\mathrm{pH}$ and ionic concentration on behavior. Clays Clay Min. 2005, 53, 211-223. [CrossRef]

5. Barbour, S.L.; Yang, N. A review of the influence of clay-brine interactions on the geotechnical properties of Ca-montmorillonitic clayey soils from western Canada. Can. Geotech. J. 1993, 30, 920-934. [CrossRef]

6. Siddiqua, S.; Blatz, J.; Siemens, G. Evaluation of the impact of pore fluid chemistry on the hydromechanical behaviour of clay-based sealing materials. Can. Geotech. J. 2011, 48, 199-213. [CrossRef]

7. Santamarina, J.C.; Klein, K.A.; Fam, M.A. Soils and Waves; John Wiley \& Sons.: New York, NY, USA, 2001.

8. Holtz, R.D.; Kovacs, W.D.; Sheahan, T.C. An Introduction to Geotechnical Engineering, Upper Saddle River; Prentice Hall.: Hoboken, NJ, USA, 2011.

9. Gargano, S.; Lirer, S.; Liguori, B.; Flora, A. Effect of the pore fluid salinities on the behaviour of an electrokinetic treated soft clayey soil. Soils Found 2020, 60, 898-910. [CrossRef]

10. Pulat, H.F.; Yukselen-Aksoy, Y.; Egeli, İ. The effect of soil mineralogy and pore fluid chemistry on the suction and swelling behavior of soils. Bull. Eng. Geol. Environ. 2014, 73, 37-42. [CrossRef]

11. Madsen, F.T.; Müller-Vonmoos, M. The swelling behaviour of clays. Appl. Clay Sci. 1989, 4, 143-156. [CrossRef]

12. ASTM D854. Standard Test Methods for Specific Gravity of Soil Solids by Water Pycnometer; ASTM: West Conshohocken, PA, USA, 2014. [CrossRef]

13. ASTM D422. Standard Test Method for Particle-Size Analysis of Soils; ASTM: West Conshohocken, PA, USA, 2007. [CrossRef]

14. ASTM D4318. Standard Test Methods for Liquid Limit, Plastic Limit, and Plasticity Index of Soils; ASTM: West Conshohocken, PA, USA, 2005. [CrossRef]

15. BSI. Methods of Test for Soils for Soils for Civil Engineering Purposes. BS 1377 1990; British Standards Institute: London, UK, 1990.

16. Jang, J.; Carlos Santamarina, J. Fines Classification Based on Sensitivity to Pore-Fluid Chemistry. J. Geotech. Geoenvironmental Eng. 2016, 142, 06015018. [CrossRef]

17. Houlsby, G.T. Theoretical analysis of the fall cone test. Géotechnique 1982, 32, 111-118. [CrossRef]

18. Koumoto, T.; Houlsby, G.T. Theory and practice of the fall cone test. Géotechnique 2001, 51, 701-712. [CrossRef]

19. Spagnoli, G. Comparison between Casagrande and drop-cone methods to calculate liquid limit for pure clay. Can. J. Soil Sci. 2012, 92, 859-864. [CrossRef]

20. Santamarina, J.C.; Klein, K.A.; Wang, Y.H.; Prencke, E. Specific surface: Determination and relevance. Can. Geotech. J. 2002, 39, 233-241. [CrossRef]

21. Chapuis, R.P.; Aubertin, M. On the use of the Kozeny-Carman equation to predict the hydraulic conductivity of soils. Can. Geotech. J. 2003, 40, 616-628. [CrossRef]

22. Muhunthan, B. Liquid limit and surface area of clays. Géotechnique 1991, 41, 135-138. [CrossRef]

23. Sanzeni, A.; Colleselli, F.; Grazioli, D. Specific Surface and Hydraulic Conductivity of Fine-Grained Soils. J. Geotech. Geoenvironmental Eng. 2013, 139, 1828-1832. [CrossRef]

24. Jang, J.; Santamarina, J. Closure to "Fines Classification Based on Sensitivity to Pore-Fluid Chemistry" by Junbong Jang and J. Carlos Santamarina. J. Geotech. Geoenvironmental Eng. 2017, 143, 07017013. [CrossRef]

25. Dastider, A.G.; Chatterjee, S.; Basu, P. Advancement in Estimation of Undrained Shear Strength through Fall Cone Tests. J Geotech Geoenvironmental Eng. 2021, 147, 04021047. [CrossRef]

26. Llano-Serna, M.A.; Farias, M.M.; Pedroso, D.M.; Williams, D.J.; Sheng, D. Considerations on the Experimental Calibration of the Fall Cone Test. Geotech. Test J. 2018, 41, 20170205. [CrossRef]

27. Zhang, F.; Wang, G.; Kamai, T.; Chen, W.; Zhang, D.; Yang, J. Undrained shear behavior of loess saturated with different concentrations of sodium chloride solution. Eng. Geol. 2013, 155, 69-79. [CrossRef]

28. Dolinar, B.; Trauner, L. The impact of structure on the undrained shear strength of cohesive soils. Eng. Geol. 2007, 92, 88-96. [CrossRef] 
29. Palomino, A.M.; Burns, S.E.; Santamarina, J.C. Mixtures of fine-grained minerals kaolinite and carbonate grains. Clays Clay Min. 2008, 56, 599-611. [CrossRef]

30. Casagrande, A. Classification and identification of soils. Trans Am. Soc. Civ. Eng. 1948, 113, 901-930. [CrossRef]

31. Jang, J.; Waite, W.F.; Stern, L.A.; Collett, T.S.; Kumar, P. Physical property characteristics of gas hydrate-bearing reservoir and associated seal sediments collected during NGHP-02 in the Krishna-Godavari Basin, in the offshore of India. Mar. Pet. Geol. 2019, 108, 249-271. [CrossRef]

32. Waite, W.F.; Jang, J.; Collett, T.S.; Kumar, P. Downhole physical property-based description of a gas hydrate petroleum system in NGHP-02 Area C: A channel, levee, fan complex in the Krishna-Godavari Basin offshore eastern India. Mar. Pet. Geol. 2019, 108, 272-295. [CrossRef]

33. Carrier, W.D. Goodbye, Hazen; Hello, Kozeny-Carman. J. Geotech. Geoenvironmental Eng. 2003, 129, 1054-1056. [CrossRef]

34. Zhai, Q.; Rahardjo, H.; Satyanaga, A. A pore-size distribution function based method for estimation of hydraulic properties of sandy soils. Eng. Geol. 2018, 246, 288-292. [CrossRef]

35. Liu, J.; Xu, Q.; Wang, S.; Subramanian, S.S.; Wang, L.; Qi, X. Formation and chemo-mechanical characteristics of weak clay interlayers between alternative mudstone and sandstone sequence of gently inclined landslides in Nanjiang, SW China. Bull. Eng. Geol. Environ. 2020, 79, 4701-4715. [CrossRef]

36. Collett, T.S.; Boswell, R.; Waite, W.F.; Kumar, P.; Roy, S.K.; Chopra, K.; Singh, S.K.; Yamada, Y.; Tenma, N.; Pohlman, J.; et al. India National Gas Hydrate Program Expedition 02 Summary of Scientific Results: Gas hydrate systems along the eastern continental margin of India. Mar. Pet. Geol. 2019, 108, 39-142. [CrossRef]

37. Chung, J.C.; Lee, M.M.; Kang, S.H. Experimental study of load characteristics of buried and exposed large-diameter pipelines using fiber-optic strain sensor. J. Ocean Eng. Technol. 2020, 34, 194-201. [CrossRef]

38. Sawyer, D.E.; Mason, R.A.; Cook, A.E.; Portnov, A. Submarine Landslides Induce Massive Waves in Subsea Brine Pools. Sci. Rep. 2019, 9, 128. [CrossRef]

39. Gregersen, O. The quick clay landslide in Rissa, Norway. Nor. Geotech. Inst. Publ. 1981, 135, 1-6.

40. Cao, S.C.; Jang, J.; Jung, J.; Waite, W.F.; Collett, T.S.; Kumar, P. 2D micromodel study of clogging behavior of fine-grained particles associated with gas hydrate production in NGHP-02 gas hydrate reservoir sediments. Mar. Pet. Geol. 2019, 108, 714-730. [CrossRef] 